\title{
発話・行動分析に基づく認知症者を対象とした スケジュール呈示機器の有効性長期評価
}

\author{
石渡利 奈 $^{1 \dagger}$ ，井上剛伸 ${ }^{1}$ ，鎌田 実 $^{2}$, 小竹元 基 $^{2}$, 矢尾板 保 $^{3}$ ，成田拓 也 ${ }^{2}$ \\ 1 国立障害者リハビリテーションセンター研究所， ${ }^{2}$ 東京大学， 3 矢尾板記念会
}

\begin{abstract}
要旨 : 情報を視覚的に呈示することで認知症者の情報の把握を支援する機器（以下，情報呈示機器）が開発されているが, 従 来の評価は主観評価などに限られ，認知症者が機器の使用を学習する過程や日常生活での有効性が充分に明らかになっていな かった．本研究では，情報呈示機器の有効性を，認知症者が機器の使用に慣れ，活用できるようになるまでの過程を含めてよ り詳細に明かにすることを目的とし，1 日の予定を呈示する機器について，現場密着型方針による4 ケ月間の臨床評価を行った. ユーザーの発話と行動を分析した結果，情報を把握できる割合は，導入前の $50 \%$ から導入 6 週間で $97 \%$ まで向上し，最終的に $100 \%$ に達した。 人に聞かず機器を見て情報を把握できた割合も, 時間経過とともに増加し, 導入前の $0 \%$ から最終的に $57 \%$ ま で向上した．なお，機器の使用を促す方策として，目立つ配色を用いることが有用であった。
\end{abstract}

キーワード：認知症，機器，発話，行動，有効性

\section{1.はじめに}

認知症では，記憶障害のために，今日の日付や 1 日の予 定など，生活の基本となる情報の把握が困難になる。情報 の把握の困難は, 自発的な行動を取りにくくし, 間違った 行動, 不安などを引き起こすことで, 生活に支障をもたら している. また, この状況に対処するため周囲に繰り返し 質問をするケースもあり，介護者への負担も課題となって いる ${ }^{1)}$.

このような情報の把握の困難を軽減する手段として, 認 知症者が必要とする情報を視覚的に呈示する機器（以下, 情報呈示機器）が開発されている. 代表的な情報呈示機器 には，日付や曜日を示す自動カレンダー ${ }^{1)}$ や，服薬などを 促すデイナビゲーター ${ }^{2)}, 1$ 日の予定を知らせるスケジュー ル呈示機器 3) などがある.

情報呈示機器の有効性として, Topo らは, 認知症者 50 名 を対象に自動カレンダーの使用評価を行い，7，8 割の認知 症者, 介護者が「機器が役立った」と回答したことを報告 している ${ }^{1)}$. また, Holthe らも, 21 名の認知症者に自動力 レンダーを導入し, 約半数で日付や曜日の混乱の解消に効 果があったことを報告している ${ }^{4}$.

これらの研究により, 機器の活用が期待される一方, 従 来の評価は, 主にインタビューを介した主観評価によるた めに詳細が明らかとなっておらず，有効であったケースに おいて，実際にどのような状態から，どのような過程を経 て，どの程度，情報を把握できるようになったかなど，今後，

2012 年 7 月 9 日受付 2012 年 10 月 28 日受理

${ }^{\dagger}$ × 359-8555 埼玉県所沢市並木 4-1

国立障害者リハビリテーションセンター研究所

石渡 利奈

Tel:04-2995-3100(2523) Fax:04-2995-3132

E-mail: ishiwata-rina@rehab.go.jp
認知症者の支援機器を開発し，現場で活用していく上で参 考となる質的量的な知見が不足している.

認知症者の機器の評価が難しい背景には, 認知症者が自 らの状態を省みて報告するのが難しいこと ${ }^{5)}$, 新しい事柄 の学習が困難で $)^{6}$, 機器の使用の学習に時間がかかること などがある，このため, 詳細な評価にあたっては, インタ ビュー以外の評価手法を用いるとともに，学習を要する機 器では，使用に慣れるまで時間をかけて評価することが必 要と考えられる．また，このような学習を支援するために， 機器の使用を促す方策も求められる。

以上より, 本研究では, 情報呈示機器の有効性を, 認知 症者が機器の使用に慣れ，活用できるようになるまでの過 程を含めてより詳細に明らかにすることを目的とし，1 日の 予定を呈示する機器（以下，スケジュール呈示機器）を例 として, 現場密着型方針による 4 ケ月間の臨床評価を行っ て, 音声・画像データを基にユーザー（機器の使用者）の 発話・行動を分析した. この結果により, 機器の使用の過 程を，情報の把握に関するユーザーと周囲の関係者の発話, 行動の変化から記述するとともに，スケジュール（1 日の予 定）の情報が必要なときに把握できた割合（以下，情報把 握率）と，人に聞かず機器を見て情報を把握できた割合（以 下, 自立度) の変化を求めた. また, 機器の使用を促す方 策として, 目立つ配色を用いることの効果を調べた.

本稿では, 2 章に, 本研究で採用した Step $1 \sim 6$ から成る 現場密着型の開発・評価方針, 3 章に, 先の報告 ${ }^{3)}$ に記し た開発（Step 1～5）の概略を示し，4 章で，評価（Step 6） の詳細を報告する.

なお, 本研究は, 国立障害者リハビリテーションセンター 倫理審査委員会の承認を受け, グループホーム入居者の家 族の同意を得て行った。 


\section{2. 現場密着型の開発・評価方針}

認知症者の機器の開発や評価では, ユーザーの真のニー ズ（必要としていること）の把握, 認知症者の複雑な特徵 の考慮, インタビューや質問紙調査などによる従来の手法 が適用しにくいこと, などが課題になる ${ }^{3)}$ 。 そこで, 本研 究では, 認知症者の生活の場で, 機器のモックアップ（実 物模型）やプロトタイプ（試作機）を実際に使ってもらい ながら進める現場密着型の研究手法 3）を用いた。本手法は, 次の 6 つの Step からなる.

Step 1: ユーザーの観察

Step $2:$ 機器のモックアップの導入

Step 3: 発話・行動分析によるモックアップの評価

Step 4 : 機器の仕様の決定

Step 5 : プロトタイプの製作

Step 6 : 発話・行動分析によるプロトタイプの評価

\section{Step1-5：スケジュール呈示機器の開発 3)}

\subsection{Step 1 : ユーザーの観察}

(1) 方法

8 〜 名の認知症者が専門職員の援助を受けながら共同 生活を営む「グループホーム」で参与観察を行った。 参与 観察は, 文化人類学などで用いられてきた質的研究法の一 つで, 研究者が対象となる集団の生活に一員として参加し, そこで起きている事柄を多角的に把握する手法である7). 本研究では, 東京都と栃木県の 2 箇所のグループホームに, 7 日間，9 17 時の間，2名の研究者が交代で滞在し，食堂 や居間で起きている事柄の観察を行った.

\section{(2) 結果}

入居者は，「昼ごはんは食べたかしら？」，「昼ごはんは何 時?」,「いま何時?」,「今日は何日？」など, 出来事やそ の予定時刻，現在時刻，日付などについて，繰り返し聞い ていた.この状況に対し，納得するまで質問に職員が答え る，予定表を自室に貼りだすなどの支援が行われていたが， 職員が周囲におらず対応できていないケースがあることや， 予定表が目立たず活用されていない実態が明らかとなった。

（3）スケジュール呈示機器のコンセプト

以上より，日々の出来事の予定時刻，現在時刻，日付や 曜日を認知症者にわかりやすい方法で呈示する機器のコン セプトを考えた。 なお, 機器の仕様を決めるため, モック アップを用いて，情報の呈示に適した場所（以下，呈示場 所)，呈示すべき内容（以下，呈示内容），呈示に適した方 法（以下，呈示方法）を調べることとした。

\subsection{Step2-3: 機器のモックアップの導入と発話・行動分析 による評価}

(1) 方法

ホワイトボードとマグネットシート，時計を用い，図 1 に示すモックアップを製作した。このモックアップは，グ
ループホームで用いるスケジュール呈示機器を想定し, 1 〜 $2[\mathrm{~m}]$ 離れたところからも目視が可能な実物大（W600[ mm] $\times \mathrm{H} 900[\mathrm{~mm}] \times \mathrm{D} 10[\mathrm{~mm}] ）$ とした. 本モックアップを前述 の栃木県のグループホームに 19 日間導入し, 呈示場所, 呈 示内容，呈示方法を変えて比較を行った。

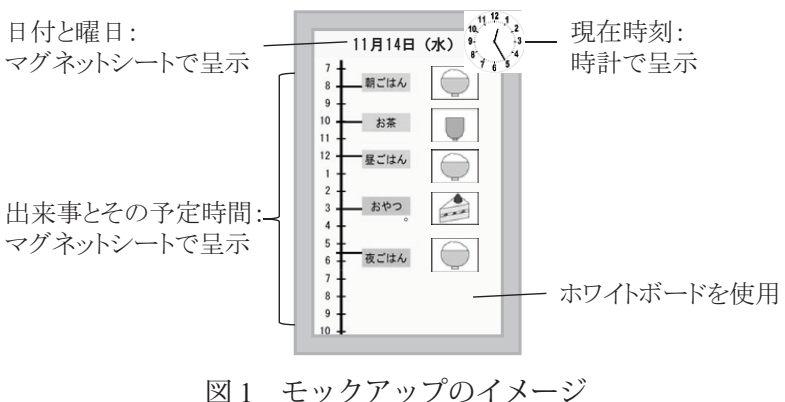

呈示場所の比較では，モックアップを入居者が日中多く の時間を過ごす【居間】，または【食堂】の 2 箇所に設置し た.また，呈示内容，呈示方法の変更は，手動で行うこと とし, 以下に詳細を示すホワイトボード上のマグネットシー トの貼り替え，時計の差し替えを行った。

呈示内容については，参与観察の結果より，候補として 【出来事（朝ごはん，お茶，昼ごはん，おやつ，夜ごはん） とその予定時刻】，【現在時刻】【日付と曜日】を呈示する こととした.これらの呈示内容について, 図 2 に示す呈示 方法の異なるマグネットシート，時計を用意した。

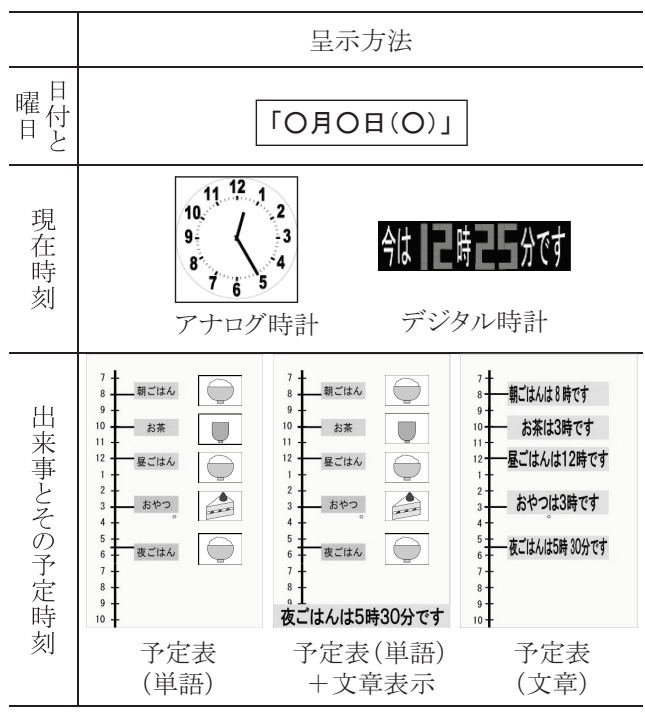

図 2 モックアップ上の呈示内容と呈示方法 （現在時刻について 2 種の呈示方法を比較, 出来事とその予定時刻 について，3 種の呈示方法を比較）

呈示方法は, 出来事と予定時刻について, マグネットシー トを用い，3 種（1)予定を単語とイラストで示す【予定表 (単語)】, (2)予定を文章で示す【予定表（文章)】, (3)予定表 （単語）と次の予定の文章表示を組み合わせた【予定表（単 語）十文章表示】）を比較した。また，現在時刻は，時計を 
用い，2 種（1）【アナログ時計】と(2)【デジタル時計】）を 比較した．日付と曜日については, マグネットシートを用い, 【○月○日（○）】の呈示を行った（図 2).

続いて，上述のモックアップを使用したユーザーの発話 および行動（モックアップ正面の音声・画像データ）を, モックアップに内蔵した Web カメラ (Logicool, Qcam QV700N）により記録した。また，データ収集と同時に，2名の 研究者が交代で参与観察を行った。

記録した入居者 9 名の発話抢よび行動データについ て, 発話があり, データ収集が可能であった $\mathrm{A} \sim \mathrm{F}$ の 6 名 分（84～ 91 歳女性, $\mathrm{N}$ 式老年者用精神状態評価尺度（NM スケール $)^{8)} 42 \sim 23$ 点, 軽度〜中等度（表 1)）の分析を 行った. 分析では, 視認しやすさ（入居者がカメラに映り 込んでいる総時間数により評価）と使用頻度（接近・指差 し, 機器に関する発話の回数）により, 適切な呈示場所を 調べた。 また, 呈示内容の各候補に関する発話の日数により, 関心が高い呈示内容を調べた。さらに，呈示方法の各候補 に関するユーザーの理解度（正しく情報を読み取れた回数 が，情報を読み取ろうとした総回数に占める割合）により， 適切な呈示方法を調べた。

表 1 入居者の属性

\begin{tabular}{c|c|c|c|c}
\hline 入居者 & 性別 & 年齢 & $\begin{array}{c}\text { N式老年者 } \\
\text { 用精神状態 } \\
\text { 評価尺度 }\end{array}$ & 重症度 \\
\hline $\mathrm{A}$ & 女 & 88 & 23 & 中等度 \\
$\mathrm{B}$ & 女 & 91 & 37 & 軽度 \\
$\mathrm{C}$ & 女 & 90 & 37 & 軽度 \\
$\mathrm{D}$ & 女 & 90 & 42 & 軽度 \\
$\mathrm{E}$ & 女 & 84 & 25 & 中等度 \\
$\mathrm{F}$ & 女 & 88 & 37 & 軽度 \\
\hline
\end{tabular}

(2) 結果

呈示場所については, 居間に比べて食堂に設置した場合 の方が, 映り込みが多く, 使用頻度も高かった. このこと から, 視認しやすい場所（食堂）に設置することで, 情報 を把握しやすくなることが示唆された.

呈示内容については, 出来事, 特に次の予定（現在から みた直後の出来事一例 : 現在が 9 時の場合, 次の予定は「お 茶」), および現在時刻に関する発話が多く, 関心が高いこ とがわかった. 出来事は把握できていない状況があったが, 現在時刻はグループホーム内のアナログ時計により把握が できていた．なお，日付と曜日に関する発話はほとんどな かった. 以上より, 出来事の情報の呈示が必要と考えられた.

呈示方法については, 出来事と予定時刻の呈示に関して, 予定表（単語）十文章表示の理解度が最も高く, 全てのユー ザーで 100\% 理解ができていた。一方, 予定表（単語）ま ま たは，予定表（文章）は，1名のユーザーで読攵間違いが あり, 理解度が低かった。一方, 現在時刻の呈示に関して, アナログ時計は理解度が高く, 全てのユーザーで $100 \%$ 理 解できていたが, デジタル時計は 1 名のユーザーで読み間 違い（理解度 33\%）があり, 理解度が低かった.

\subsection{Step4-5 : 機器の仕様の決定とプロトタイプの製作}

前節の結果より, スケジュール呈示機器の仕様を以下の ように決定した.

・呈示場所 : 食堂

- 呈示内容：出来事

・呈示方法：予定表（単語）十文章表示

以上の仕様に基づき, 図 3 に示すスケジュール呈示機器 のプロトタイプを製作した．上部は時間軸（LED の消灯で 時間経過を表示）に沿った予定表（単語），下部は電光揭示 板を用いた次の予定の文章表示とした。

\section{Step6：スケジュール呈示機器の臨床評価 4.1 目的と方針}

Step1-5 で開発したスケジュール呈示機器（図 3）につい て, 有効性を明らかにするための臨床評価（Step6）を行っ た. Step3では, モックアップの短期評価を行って, 場所に よる機器の使用頻度の違い, 関心のある内容, 理解度の高 い呈示方法などを分析し, 機器の仕様（呈示場所, 呈示内 容，呈示方法）を決定した。これに対し, Step6では，上述 の仕様に基づくプロトタイプの長期評価を行って, 機器の 使用の過程と導入前後の情報把握率, 自立度の变化を分析 し，機器の有効性を評価した。

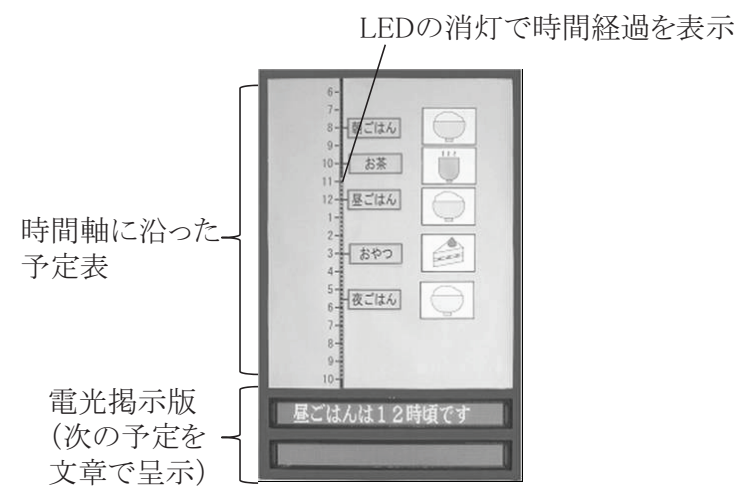

図 3 プロトタイプ

\section{2 方法}

\section{(1) 臨床評価}

栃木県のグループホームに，4 ケ月間機器を設置し，関心 が高かった「次の予定」の情報の把握に焦点を当てて, 機 器により情報を把握できるようになるまでの過程と, 導入 前後の情報把握率, 自立度の変化を調べた. 対象として, 発話量が多く, 毎朝の頻回な質問 (「朝ごはんは何時?」) により，情報の把握に関するデータを確実に収集すること ができる F（88 歳女性, NM スケール 31 点, 認知症軽度) を選んだ.

機器は, 図4 のように食堂に設置し, 機器上方の集音マ イク（CARRAY，SM-2）により, 食堂付近の音声を記録 した. また, 機器内部の 2 台のピンホールカメラ（コロナ 電業, TR-06CPM）により, 機器正面, および $\mathrm{F}$ の居室入 り口の画像を撮影した. さらに, マジックミラー付きス ピーカ内に設置したネットワークカメラ (Panasonic, BB- 


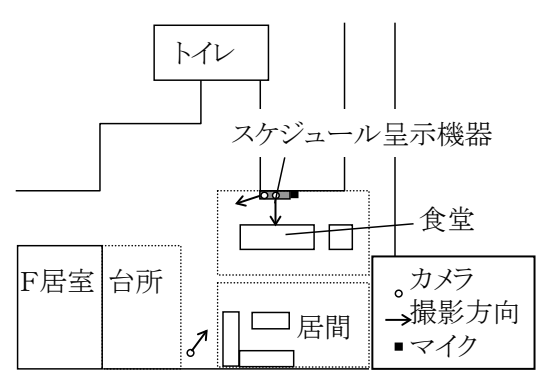

図 4 評価環境

（グループホームの見取図と機器，カメラ・マイクの設置場所）

HCM381）により食堂全体の画像を撮影した，以上の音声・ 画像データをハードディスクレコーダー（SANYO，VDH8000, VDH-F2160）に記録した。 データ収集は, ベースライ ン期（導入前：情報呈示なし）の分析から, F が最も必要と した情報（朝ごはんの予定時刻）の把握について調べるた め, 朝食前 $(6: 00 \sim 8: 00)$ の時間帯に行った. この間, 電 光掲示板の表示は, $6: 00 \sim 7: 30$ は「朝ごはんは 8 時頃です」, 7:30〜8:00 は「もうすぐ朝ごはんです」とした.

グループホームの壁面には, 様々な掲示物が貼られてお り, 機器の存在が目立ちにくくなっている. そこで, 機器 に注意を引き, 機器を使用して情報を把握することの学習 を支援するため, 機器の背景色と枠を「白色十木枠」から, より目立つ「黄色十赤枠」に変えて, その効果を評価し た. 期間ごとの情報呈示の条件を表 2 に示す。ベースライ ン $1,2 （ 0,17$ 週）は呈示なし，第 $1 ， 5$ 期（1３，16 週） は「白色十木枠」, 第 2-4 期 $(4 \sim 15$ 週 $)$ は「黄色十赤枠」 とした。 な报，音声・画像データの収集は，第 3 期を除く 0 〜6 週抢よび $15 \sim 17$ 週で実施した.

表 2 期間ごとの情報呈示の条件

\begin{tabular}{c|c|c|c}
\hline 週 & 期間 & $\begin{array}{c}\text { 情報呈示の } \\
\text { 条件 }\end{array}$ & 音声および画像計測 \\
\hline W0 & ベースライン 1 & 呈示なし & あり \\
W1-3 & 第1期 & 白色+木枠 & あり \\
$W 4-6$ & 第2期 & 黄色+赤枠 & あり \\
W7-14 & 第3期 & 黄色十赤枠 & なし \\
W15 & 第4期 & 黄色十赤枠 & あり \\
W16 & 第5期 & 白色十木枠 & あり \\
W17 & ベースライン2 & 呈示なし & あり \\
\hline
\end{tabular}

(2) 解析

音声データを基に，スケジュールに関する全発話のテー プ起こしを行い, 発話の日付, 時刻, 話者, 発話内容を記 録した。 また，画像データを基に，スケジュールに関する 発話や機器を見る行動（以下, 情報把握行動）に関し, 発 話抢よび行動前後の移動先, 行動内容を記録した. 情報把 握行動では, 情報が把握できるまで（または把握するのを あきらめるまで）何度か質問が繰り返されるが, 会話が途 切れるまでを 1 回の情報把握行動とした.

表 2 の期間ごとに情報把握行動の回数を調べ, データを
収集した日数で割って7をかけることにより，「週あたりの 情報把握行動の回数 [ 回 / 週 ]」を求めた. また情報把握行 動のパターンを手段（職員または入居者に聞く，機器を見 る）と可否（情報が把握できたか否か）により, 表 3 に示 す(1)〜9に分類した．このパターンに基づき，「情報把握率」 を次式で定義して求めた。（R1: 情報把握率 \%, S : 情報が 把握できたパターン（11，(2)，(4)，(5)，(7)）による週あた りの情報把握行動の合計回数 [ 回 / 週 ], L : 能動的に情報 を把握しようとしたパターン（8以外）による週あたりの 情報把握行動の合計回数 [ 回 / 週 ] )

$$
\mathrm{R} 1 \%=100 \times \mathrm{S} \text { [ 回 / 週 ] L [ 回 / 週 ] 式 (1) }
$$

また, 「自立度」も, 次式で定義して求めた。（R2: 自立 度 $\%, \mathrm{D}$ ：人に聞かず，機器を見て情報を把握したパター ン（7，，8）による週あたりの情報把握行動の合計回数 [ 回 / 週 ], B : 週あたりの全情報把握行動の合計回数 [ 回 / 週 ])

$$
\mathrm{R} 2 \%=100 \times \mathrm{D}[\text { 回 } / \text { 週 }] / \mathrm{B} \text { [ 回 / 週 ] }
$$

表 3 情報把握行動のパターン

\begin{tabular}{l|l}
\hline 型 & \multicolumn{1}{|c}{ 説明 } \\
\hline (1) & 職員に聞いて、情報を把握できた \\
(2) & 職員に聞いて、機器を見るよう促されて情報を把握できた \\
(3) & 職員に聞いたが、伝わらず、情報が把握できなかった \\
(4) & 入居者に聞いて、機器を見た入居者から情報を把握できた \\
(5) & 入居者に聞いたが答えが得られず、自ら機器を見に行って \\
(6) & 入居者に聞いたが情報が把握できなかった \\
(7) & 自ら機器を見に行って情報を把握できた \\
(8) & 機器が自然に目に入り、情報を把握できた \\
(9) & 機器を見に行ったが、情報呈示がないために、情報が把握 \\
できなかった(ベースライン2) \\
\hline
\end{tabular}

\section{3 結果}

（1）手段による情報の把握の可否

表 4 に, パターン, 期間ごとの週あたりの情報把握行動 の回数 [ 回/週 ]を示す（例：パターン(3)「職員に聞いたが, 伝わらず，情報が把握できなかった」は，第 1 期に $0.3[$ 回 / 週 ] 発生 (3 週間の間に 1 回発生)). 職員に聞いた場合 (パ ターン(1)〜 (3)）で, 情報が把握できなかったのはパターン (3)のみで, パターン(3) 第 1 期に 1 回発生したものの, 職員に聞いた他の情報把握行動はパターン(1)か(2)で全て情 報が把握できていた（表4）.

一方，入居者（A，E）に聞いた場合（パターン(4)〜 (6) は, 機器が E の視界に入っており読み取った情報を伝えた 1 回（パターン(4), 第 5 期) を除く, 全ての回で情報が把 握できていなかった。 なお, 機器を見た場合は, 職員に促 されて見る場合 (パターン(2)), 自発的に見る場合 (パター ン (5)，(7)，自然に目に入る場合（パターン8）の全てで情 報が把握できていた（表 4)。以上より, 職員に聞いた場合, 
表 4 週あたりの情報把握行動の回数［回 / 週 $]$

\begin{tabular}{cccccccccc}
\hline & (1) & (2) & (3) & (4) & (5) & (6) & (7) & (8) & (9) \\
\hline BL1 & 4.7 & 0.0 & 0.0 & 0.0 & 0.0 & 4.7 & 0.0 & 0.0 & - \\
第1期 & 4.3 & 1.3 & 0.3 & 0.0 & 0.0 & 2.2 & 0.9 & 3.2 & - \\
第2期 & 1.7 & 3.3 & 0.0 & 0.0 & 1.3 & 0.3 & 6.3 & 1.3 & - \\
第4期 & 2.0 & 1.0 & 0.0 & 0.0 & 0.0 & 0.0 & 3.0 & 1.0 & - \\
第5期 & 1.0 & 1.0 & 0.0 & 1.0 & 1.0 & 0.0 & 3.0 & 0.0 & - \\
BL2 & 5.0 & 0.0 & 0.0 & 0.0 & 0.0 & 1.0 & 0.0 & 0.0 & 4.0 \\
\hline
\end{tabular}

および機器を見た場合は, 情報が把握できており, 入居者 に聞いた場合は，情報が把握できていないことがわかった.

\section{（2）機器の使用による情報の把握の状況の変化}

導入前〜導入初期では，入居者に聞いた全ての回（パ ターン6のみ発生, ベースライン 1 で 4.7 [ 回/ 週 ], 第 1 期 2.2[回/週］）で情報が把握できていなかった（表 4).こ のため, 1 回の情報把握行動の中で質問を繰り返し,「わか んねえ.」という嘆きの発言もみられた。しかし, 導入後約 1 ケ月以上経った第 2 期では,「朝ごはんは何時だっけ?（E 答えられず）（機器の方を見て）あそこにあるんかな. 書い てあるな，あれ。（機器を見て）8 時だ.」といったように， 入居者に聞くことにより情報が把握できなくても, 自ら機 器を利用して情報を把握できる回（パターン(5), 1.3[ 回/ 週 ]）が増加した（表 4). また, 導入後約 3 ケ月経った第 4 期には，A，Eに質問することはなくなり，代わりに自ら機 器を見に行くようになった（(大居者に聞くパターン(4)～(6) が 0.0 [ 回 / 週 ], 機器を見に行くパターン(7)が 3.0 [ 回 / 週 ]) （表 4). なお, 情報呈示をやめたベースライン 2 においては, 機器の前に来て, 職員に「何時だっけ?そこらに書いてん だよな. 朝食は何時だとかなんてさ. 消えちゃったんかい.」 と聞いたり, 機器に向かって「何時なんだい?」と独り言 を言う事例が見られた. 以上より, 時間経過とともに機器 を使用して情報を把握することを学習し，4 ケ月間の使用に より機器による情報の把握が習慣化されたことがわかった.

\section{（3）情報把握率}

図 5 に期間ごとの情報把握率を示す。図中, 黒がスケ ジュールの情報が必要なときに把握できた割合（情報把握

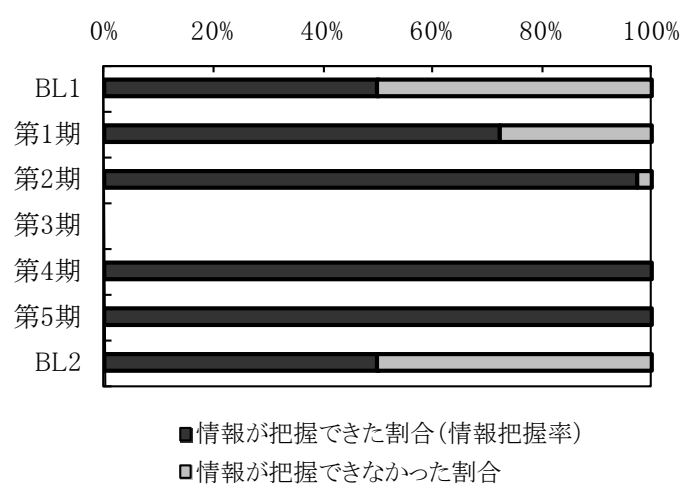

図 5 情報把握率の変化
率）を示し，グレーが把握できなかった割合を示す．導入 前（ベースライン 1) は, 職員が周囲にいる時しか情報を把 握できなかったため, 情報把握率は $50 \%$ であった。 しかし， 導入後は, 機器からも情報を把握できるようになったため, 情報把握率は，導入後約 1 ケ月の第 2 期で $97 \%$, 導入後約 3 ケ月以降の第 4，5期で $100 \%$ まで向上した。一方，情報 呈示をやめたベースライン 2 では情報把握率は $50 \%$ に低下 し，導入前の状態に戻ったことが確かめられた（図 5). 以 上より, 機器の利用を扎よそ1 ケ月間で学習し, 最終的に, 機器を利用することで, 情報を必要とした全ての回で情報 が把握できるようになったことが確かめられた.

\section{（4）自立度}

図 6 に期間ごとの自立度を示す。図中，黒が人に聞かず 機器を見て情報を把握できた割合 (自立度), グレーが人に 聞いた割合, 白が機器を見たが情報呈示がされていなかっ た割合を示す。導入前は情報の把握を全て他者に依存して （人に聞いて）いたが (自立度 $0 \%$ ), 導入後は自ら機器を見 る回が次第に増え，第 4 期では，57\%まで自立度が向上し た（図 6). 以上より, 機器の利用により, 情報の把握の自 立度が向上したことが示された。

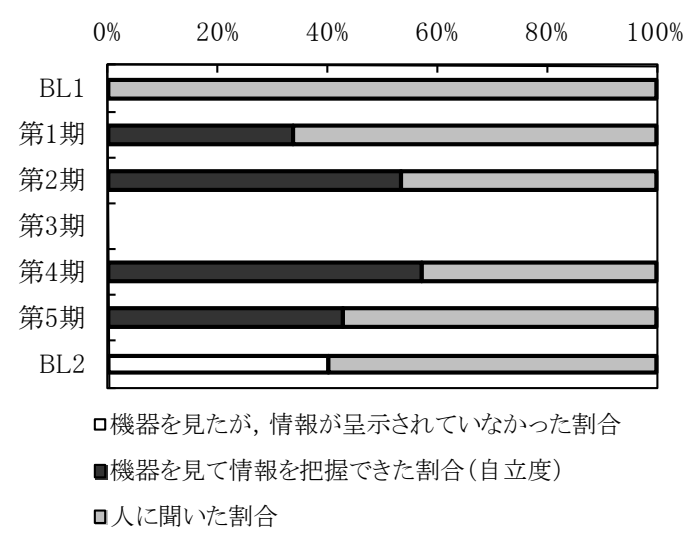

図 6 自立度の変化

（5）配色の効果

第 1 期から第 2 期で, 呈示機器の配色を「白色十木枠」 から「黄色十赤枠」に変えた結果, 自ら機器を見に行く回 が大幅に増えた（パターン(7)が 0.9 から 6.3 [ 回 / 週 ] に増加） (表 4).また, 第 4 期から第 5 期で, 呈示機器の配色を「黄 色十赤枠」から「白色十木枠」に戻した結果, 自ら機器を 見に行く回数は変わらなかったものの, 機器を見つけられ ず，「朝ご飯は何時って書いてあったっけ?」と他の入居者 に聞くケースが生じた. 以上より, 機器の配色に目立つ色 を用いることで, 機器の使用を効果的に促すことができる 可能性が示唆された.

\section{4 考察}

（1）機器の有効性，および機器を活用できるようになるま での過程

スケジュール呈示機器の利用により，情報把握率が導入 
前の 50 から $100 \%$ に向上し, 自立度も $50 \%$ 以上に向上した ことから, 情報呈示機器が情報の把握を効果的に支援し得 ることが示唆された. また, 一般的に, 認知症者は, 新し (事柄の学習が困難 (6) とされるが, 本研究では, 1 ケ月程 度の時間をかけることで, 機器の使用が可能となった実例 を示した。 なお，有効性が最大（今回は $100 \%$ ）となるまで は 1 ケ月以上かかったことから, 認知症者を対象とした機 器の有効性評価は, 経過を確認し, 効果が安定した段階で 行うことが必要と考えられる.

本研究は, グループホームで実施しため, 職員が周囲に いるとき（情報を必要とした機会の半分）は情報が把握で きていたが, 独居や家族が日中不在の在宅認知症者では, より多くの場面で情報が把握できていない状況が予想され る. 認知症の重症度や生活の背景により必要な情報の内容 は異なるものの, 本研究で示した方法による視覚的な情報 の呈示は在宅でも実践可能であり, 在宅認知症者の情報の 把握の困難を大きく改善し得ることが期待される. また, 認知症者の繰り返しの質問は，24 時間を共に過ごす家族な ど介護者の大きな負担となるが ${ }^{1)}$, 今回, 機器の利用により, 情報を把握したい時に人に聞く割合が減った（自立度が向 上した）ことから, 機器が介護負担の軽減にも役立つこと が示唆される.

一方, 間接的な効果として, 導入前は, 食事の時間がわ からないため, 食堂で「退屈だなあ.」と言いながら待って いた $\mathrm{F}$ が，導入後，時間の見通しを持ち，「(食事まで) あ と一時間あるから, 部屋へ戻って休んでこょう」と計画的 な行動を取るようになった。このことから，機器を用いた 支援により, 認知症者の行動選択の幅が広がり, より自発 的な行動が取れるようになることが期待される.

\section{（2）機器の使用を促す方策}

配色については, 第 2 期に「黄色十赤枠」に変えた際に, 自ら機器を見に行く機会が大幅に増えたこと, 第 5 期に「白 色十木枠」に戻した際に機器を見つけられないケースが生 じたことから，機器の使用を促す上で，目立つ配色に効果 がある可能性が示された. アルッハイマー病患者では, 赤 や黄などの認識率が良く ${ }^{9)}$, 欧州では認知症者がトイレを 認識しやすいよう便座を赤く塗るなどの支援が行われてい るが，本研究で示した結果は，このような支援の妥当性を 裏付けるものと考えられる.

\section{（3）現場密着型の研究手法}

本研究では, 認知症者を対象に, 現場密着型の研究手法 により開発した機器について, 同手法に基づく発話・行動分 析を行って, その有効性を明らかにした. このように, 日常 生活の場でモックアップやプロトタイプを実際に使ってもら い, 非干渉に収集した音声扔よび画像データから分析を行 う手法は, 従来の手法が適用しにくい認知症者に適している と考えられ, 認知症者を対象とした家電製品等のインター フェースの開発やユーザビリティの評価にも応用可能である.

\section{（4）本研究の意義と限界}

記憶障害のある認知症者が, 情報の把握をどのように行 い, どの程度, 把握できているかの実態を調べることは容 易ではなく, 今後, 本分野の支援機器の開発を進めていく 上で, 発話・行動データ分析に基づいて機器の使用の効果 を明らかにした本研究の意義は大きい. また, 短期間の実 験により, 認知症者に適したインターフェースを調べた研 究はあるが ${ }^{10)}$, 認知症者の生活現場に長期間密着して, 機 器を使用していく過程を詳細に追った研究はほとんどなく, 認知症者が機器を利用することを覚え，有効になるまでの 過程を示した本研究は, 機器の活用を進めて行く上で貴重 な知見となる。

一方, 本研究では, 従来の研究で得られていなかった基 礎的知見を得るため, 第一段階として, 対象を限定して長 期間の発話・行動データ分析を行った. このため, 今回示 した情報把握率の数值そのものなどは, 対象や生活環境に 依存した值となっている，本研究のように，労力を要する 長期間の分析は, 多数の被験者を対象にするケースでは難 しく, 多人数でのエビデンス収集が求められる次の段階で は, 本研究を基に, 部分的なデータ分析を行うことで, 効 率的に有効性を評価できると考えられる.

\section{5. 結論}

情報呈示機器の有効性と使用の過程を詳細に明らかにす ることを目的とし, スケジュール呈示機器を例として, 現 場密着型の研究手法により臨床評価を行った結果, 以下の 結論を得た。

- 機器による視覚的な情報の呈示は, 機器の利用の学習に 時間を要する場合があるものの, 情報把握率, および自 立度の向上に有効であり, 情報の把握の困難, 介護負担 の軽減に役立つことが示唆される. また, 間接的な効果 として, 機器を用いた情報の把握の支援により, 認知症 者の行動選択の幅が広がり, より自発的な行動が取れる ようになることが期待される.

- 認知症者の機器の使用を促す方策として, 目立つ配色を 用いることが有用な可能性が示唆される.

\section{謝辞}

本研究の実施にご協力いただいた入居者と職員の皆様, 東京大学工学部の鈴木良平氏に, 心より謝意を表する。なお， 本研究の一部は, 厚生労働科学研究費補助金 (長寿科学総 合研究事業, 認知症対策総合研究事業), および文部科学研 究費補助金（基盤研究 B $: 21300213, C ： 21500536$ ）の助成 を受けた.

\section{参考文献}

1) Topo, P., Saarikalle, K., Begley, E., Cahill, S., Holthe, T. and Macijauskiene, J.: I don't know about the past or the future, 
but today it's Friday-Evaluation of a Time Aid for People with Dementia, Technology and Disability, 19, 121-131, (2007).

2) Meiland, F. J. M., Reinersmann, A., Bergvall-Kåreborn, B., Craig, D., Moelaert, F. , Mulvenna, M. D., Nugent, C., Scully, T., Bengtsson, J. E. and Dröes, R. M.: COGKNOW Development and evaluation of an ICT-device for people with mild dementia, In: Bos, L. and Blobel, B. (Eds): Medical and Care Compunetics 4, 166-177, IOS Press, (2007).

3) Inoue, T., Ishiwata, R., Suzuki, R., Narita, T., Kamata, M., Shino, M. and Yaoita, M.: Development by a Field-Based Method of a Daily-Plan Indicator for Persons with Dementia, Assistive Technology from Adapted Equipment to Inclusive Environments , 364-368, IOS Press, (2009).

4) Holthe, T., Haugen, I. and Bjoerneby, S.: Evaluation of an automatic calendar to enable time orientation for persons with memory problems, A report from the EU-project Technology, Ethics and Dementia, (1998).

5) Cahill, S., Begley, E. and Jones, K.: Technology, Dementia and Quality of Life, Hearing the Individual's Voice, Assistive Technology-Shaping the Future, 787-792, IOS Press, (2003).

6) Bjoerneby, S., Duff, P. and Outi, M.: Developing Assistive Technology for People with Dementia, Assistive TechnologyShaping the Future, 781-786, IOS Press, (2003).

7) 中澤 潤, 大野木裕明, 南 博文（編）: 心理学マニュアル 観察法, 36-45, 北大路書房, (2007).

8) 小林敏子, 播口之朗, 西村 健, 武田雅俊, 福永知子 : 行動 観察による痴呆患者の精神状態評価尺度（NM スケール）
および日常生活動作能力強化尺度 (N-ADL) の作成, 臨 床精神医学, 17(11), 1653-1668, (1988).

9) Wijk, H., Berg, S., Sivik, L. and Steen, B.: Colors discrimination, color naming and colors preferences among individuals with Alzheimer's disease, Int. J. of Geriatric Psychiatry, 14, 1000-1005, (1999).

10) 二瓶美里, 吉武宏, 武澤友広, 石渡利奈, 井上剛伸, 鎌田 実 : 軽度認知症者の認知特性と情報端末入力方式に関す る研究, バイオメカニズム学会誌, 36(3), 162-170, (2012).

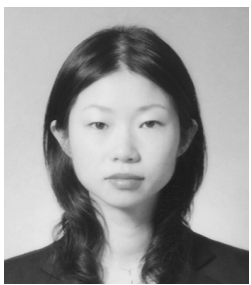

石渡 利奈 (いしたたりな)

2005 年慶應義塾大学大学院理工学研究科 博士課程満期退学. 工学修士. 2005 年国 立障害者リハビリテーションセンター研 究所福祉機器開発部研究員. 現在, 認知 症者を対象とした支援機器の研究開発に 従事. 日本人間工学会, 日本リハビリテーション工学協会, 生活支援工学会, 認知症ケア学会の会員 (バイオメカニズ 么学会正会員)

小竹 元基 (しのもとき)

2002 年工学博士, 現在東京大学大学院工学系研究科准教授. 現在, 筋ジストロフィ患者のための操作系の開発, パーソ ナルモビリティの研究等, 主として生活支援工学, ユーザ ビリティ評価, ヒューマンファクターの研究に従事. 


\title{
Long-term effectiveness of a Daily-Plan Indicator for Persons with Dementia evaluated by speech and behavior analysis
}

\author{
Rina ISHIWATA ${ }^{1 \dagger}$, Takenobu INOUE ${ }^{1}$, Minoru KAMATA ${ }^{2}$, Motoki SHINO ${ }^{2}$, Masashi YAOITA ${ }^{3}$, Takuya NARITA ${ }^{2}$ \\ ${ }^{1}$ Research Institute, National Rehabilitation Center for Persons with Disabilities, ${ }^{2}$ The University of Tokyo, \\ ${ }^{3}$ The Yaoita Memorial Association
}

\begin{abstract}
Some assistive technologies for persons with dementia have been developed to facilitate awareness of information by providing the information visually. However, these technologies have been evaluated by subjective assessment and learning process, and their effectiveness in daily life has not become clear yet. The purpose of this study is to investigate the effectiveness of such assistive technology including the process of familiarization and utilization for a person with dementia. A four month clinical evaluation of a daily-plan indicator was conducted using the field-based method. Results of a user's speech and behavior analysis showed that the ratio of information awareness was increased from 50 to 97 after six week of use and 100\% after four months of use respectively. The ratio of independence in information awareness had also increased from 0 to $57 \%$. The use of vivid colors was found to be helpful for increasing the use of the indicator.
\end{abstract}

Key Words : dementia, assistive technology, speech, behavior and effectiveness

Received Jul 9, 2012 Accepted Oct. 26, 2012

${ }^{\dagger}$ Rina ISHIWATA

Research Institute, National Rehabilitation Center for Persons with

Disabilities

Namiki 4-1, Tokorozawa, Saitama, 359-8555, JAPAN

Tel: 04-2995-3100(2523) Fax: 04-2995-3132

E-mail: ishiwata-rina@rehab.go.jp 